\title{
Expression of human HtrA1, HtrA2, HtrA3 and TGF- $\beta 1$ genes in primary endometrial cancer
}

\author{
JOANNA NARKIEWICZ ${ }^{1}$, SYLWIA LAPINSKA-SZUMCZYK ${ }^{2}$, DOROTA ZURAWA-JANICKA ${ }^{1}$, \\ JOANNA SKORKO-GLONEK ${ }^{1}$, JANUSZ EMERICH ${ }^{2}$ and BARBARA LIPINSKA ${ }^{1}$ \\ ${ }^{1}$ Department of Biochemistry, University of Gdansk, Kladki 24, 80-822 Gdansk; \\ ${ }^{2}$ Department of Gynecology, Medical University of Gdansk, Kliniczna 1A, 80-402 Gdansk, Poland
}

Received October 24, 2008; Accepted January 9, 2009

DOI: 10.3892/or_00000385

\begin{abstract}
The HtrA family of serine proteases takes part in cellular stress response including heat shock, inflammation and cancer. Downregulation of human HtrAl and HtrA3 genes has been reported in some cancers, including endometrial cancer (EC), suggesting a tumor-suppressor role for both genes. The mechanism of the HtrA function is not known, however, evidence exists showing that both HtrA1 and HtrA3 regulate biological processes by modulating TGF- $\beta$ signaling. In the presented study the expression of human HtrAl, HtrA2, $H \operatorname{tr} A 3$ and $T G F-\beta 1$ genes was examined in 124 endometrial tissue specimens including 88 cancers and 36 normal endometria. The expression of the tested genes was evaluated at mRNA and protein levels by semi-quantitative RT-PCR and Western blotting methods, respectively. Our results showed significant decrease of $\mathrm{HtrAl}$ and $\mathrm{HtrA3} \mathrm{mRNA}$ and protein levels in EC compared to normal tissues. The most dramatic decrease was found for $\mathrm{HtrA3}$ at both mRNA and protein levels (3.2- and 5.6-fold, respectively). Moreover, the HtrA3 protein (short isoform) was not detected in $19 \%$ of the cancers, and its level decreased from the premenopausal to the postmenopausal group. The HtrA2 protein levels were significantly lower in EC tissues compared to normal tissues. We also found a significant increase of the TGF- $\beta 1$ protein level in $\mathrm{EC}$ as well as a significant negative correlation between HtrA1/2/3 and TGF- $\beta 1$ relative protein levels. Our results showing downregulation of HtrAl and HtrA3 gene expression support previous studies suggesting a tumor suppressor role for these genes. Furthermore, our data suggest that HtrA2 may be involved in EC development as well as suggest the involvement of HtrA1, HtrA2 and HtrA3 in the inhibition of TGF- $ß$ signaling in endometrial tissues.
\end{abstract}

Correspondence to: Dr Barbara Lipinska, University of Gdansk, Department of Biochemistry, Kladki 24, 80-822 Gdansk, Poland E-mail: lipinska@biotech.ug.gda.pl

Key words: HtrA genes, endometrial cancer, $T G F-\beta 1$

\section{Introduction}

Endometrial carcinoma is the eighth most common cancer in women worldwide, typically affecting women after menopause. The most common form of endometrial tumors diagnosed (approximately 80\%) is endometrioid carcinoma, associated with endometrial hyperplasia. These tumors frequently have mutations in the ras proto-oncogene and in the PTEN tumor suppressor gene, and often show microsatellite instability. Other histological tumor types show mutations in the p53 tumor suppressor gene, but not in the PTEN gene (reviewed in ref. 1). Despite many years of research, the molecular basis of endometrial cancer is not fully understood and no clinically applicable test has yet been defined that could be used for its screening. No tumor assay has been recognized that would be useful for diagnosis or evaluating the response to therapy. Hence further biochemical and genetic research aimed at revealing the biology and to define the prognosis of the endometrial cancer is necessary.

The HtrA protein family comprises serine proteases taking part in cell protection against stress conditions. HtrA was initially identified as a heat-induced gene from Escherichia coli indispensable for bacteria survival at elevated temperatures (2). Further studies showed that HtrA acts as a serine protease degrading misfolded proteins in the periplasm at high temperatures and as a molecular chaperone at low temperatures (3). Members of the HtrA family were identified in most organisms, including four human homologues: HtrA1HtrA4. Several reports describe their implication in heat and oxidative stress response, arthritis, kidney ischemia/reperfusion, apoptosis, cancer progression and invasion (reviewed in ref. 4). The common feature of the HtrA family of proteins is a highly conserved trypsin-like serine protease domain, most of them also contain a C-terminal PDZ domain(s). The PDZ domains are the structures usually involved in proteinprotein interactions, in the case of the HtrA proteases they participate in the substrate binding (reviewed in ref. 4).

Human HtrAl (PRSS11, L56) was initially identified as a downregulated gene in SV40-transformed fibroblasts (5) and upregulated in osteoarthritic cartilage (6). The expression of HtrAl was decreased in ovarian $(7,8)$ and endometrial cancers (9), and in melanomas (10). It was shown that HtrAl overexpression in melanoma cells inhibited proliferation and chemoinvasion while downregulation promoted cell proli- 
Table I. HtrA1, HtrA2 and HtrA3 expression and the characteristics of endometrial cancers.

\begin{tabular}{|c|c|c|c|c|c|c|c|}
\hline & \multirow[b]{2}{*}{ No. of cases } & \multicolumn{2}{|c|}{ HtrAl } & \multicolumn{2}{|c|}{$H t r A 2$} & \multicolumn{2}{|c|}{ HtrA3 } \\
\hline & & mRNA & Protein & mRNA & Protein & mRNA & Protein \\
\hline Total & 124 & & & & & & \\
\hline Normal endometrium & 36 & 0.61 & 2.24 & 0.74 & 1.74 & 0.60 & 1.52 \\
\hline Endometrial cancer & 88 & $\begin{array}{l}0.33 \\
\mathrm{p}=0.000\end{array}$ & $\begin{array}{l}1.02 \\
\mathrm{p}=0.000\end{array}$ & $\begin{array}{l}0.66 \\
p=0.195\end{array}$ & $\begin{array}{l}1.25 \\
\mathrm{p}=0.001\end{array}$ & $\begin{array}{l}0.19 \\
\mathrm{p}=0.000\end{array}$ & $\begin{array}{l}0.27 \\
\mathrm{p}=0.000\end{array}$ \\
\hline \multicolumn{8}{|l|}{ FIGO stage } \\
\hline I & 64 & 0.34 & 1.01 & 0.65 & 1.26 & 0.20 & 0.27 \\
\hline II & 13 & 0.48 & 1.11 & 0.73 & 1.30 & 0.22 & 0.37 \\
\hline $\mathrm{III}+\mathrm{IV}$ & 11 & $\begin{array}{l}0.24 \\
\mathrm{p}=0.080\end{array}$ & $\begin{array}{l}1.12 \\
p=0.575\end{array}$ & $\begin{array}{l}0.73 \\
p=0.929\end{array}$ & $\begin{array}{l}0.92 \\
\mathrm{p}=0.339\end{array}$ & $\begin{array}{l}0.13 \\
\mathrm{p}=0.162\end{array}$ & $\begin{array}{l}0.14 \\
\mathrm{p}=0.894\end{array}$ \\
\hline \multicolumn{8}{|l|}{ Histological type } \\
\hline Endometrioid & 62 & 0.34 & 1.00 & 0.70 & 1.31 & 0.20 & 0.28 \\
\hline Adenosquamous & 15 & 0.33 & 1.24 & 0.57 & 1.30 & 0.20 & 0.27 \\
\hline Clear cell & 4 & 0.36 & 0.90 & 0.60 & 1.41 & 0.03 & 0.10 \\
\hline Serous & 3 & 0.57 & 0.93 & 0.67 & 0.87 & 0.15 & 0.14 \\
\hline Others & 4 & $\begin{array}{l}0.28 \\
\mathrm{p}=0.956\end{array}$ & $\begin{array}{l}1.00 \\
\mathrm{p}=0.239\end{array}$ & $\begin{array}{l}0.54 \\
p=0.500\end{array}$ & $\begin{array}{l}0.83 \\
\mathrm{p}=0.339\end{array}$ & $\begin{array}{l}0.18 \\
p=0.113\end{array}$ & $\begin{array}{l}0.60 \\
\mathrm{p}=0.883\end{array}$ \\
\hline \multicolumn{8}{|l|}{ Histological grade ${ }^{a}$} \\
\hline G1 & 35 & 0.30 & 1.05 & 0.65 & 1.40 & 0.26 & 0.28 \\
\hline G2 & 22 & 0.34 & 0.89 & 0.74 & 1.12 & 0.16 & 0.18 \\
\hline G3 & 5 & $\begin{array}{l}0.57 \\
p=0.365\end{array}$ & $\begin{array}{l}1.06 \\
p=0.505\end{array}$ & $\begin{array}{l}0.70 \\
p=0.264\end{array}$ & $\begin{array}{l}1.00 \\
\mathrm{p}=0.315\end{array}$ & $\begin{array}{l}0.14 \\
p=0.165\end{array}$ & $\begin{array}{l}0.42 \\
\mathrm{p}=0.470\end{array}$ \\
\hline \multicolumn{8}{|l|}{ Menopausal status } \\
\hline Premenopausal & 6 & 0.53 & 1.06 & 0.72 & 1.63 & 0.45 & 0.65 \\
\hline Perimenopausal & 7 & 0.56 & 0.97 & 0.74 & 1.11 & 0.14 & 0.42 \\
\hline Postmenopausal & 75 & $\begin{array}{l}0.31 \\
p=0.293\end{array}$ & $\begin{array}{l}1.02 \\
p=0.806\end{array}$ & $\begin{array}{l}0.65 \\
p=0.848\end{array}$ & $\begin{array}{l}1.23 \\
p=0.649\end{array}$ & $\begin{array}{l}0.19 \\
p=0.547\end{array}$ & $\begin{array}{l}0.23 \\
\mathrm{p}=0.050\end{array}$ \\
\hline
\end{tabular}

The median mRNA and protein relative values in different types of tissues are presented. Relative mRNA levels were calculated in the RT-PCR assay as a ratio of intensity of the HtrA band to the B-actin band amplified in the same reaction mixture. Relative protein levels were estimated by Western blotting as a ratio of the HtrA protein band intensity in the tested sample to the HtrA intensity in the reference normal sample resolved on the same gel. P-values presenting a significant trend over the tested tissue group were found by the Kruskal-

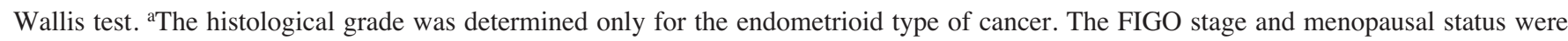
determined for all histological types of cancer.

feration (10). Moreover, downregulation of HtrAl in the ovarian cancer cell line promoted anchorage-independent growth, while exogenous expression induced cell death (8). The above facts suggested a tumor suppressor role for HtrAl. Furthermore, evidence exists showing involvement of HtrA1 in modulation of the chemotherapy-induced cytotoxicity (11).

The HtrA1 protein shows a high homology to HtrA3 with both proteins containing an $\mathrm{N}$-terminal signal sequence, an IGFBP (insulin-like growth factor binding protein) domain, a Kazal-type S trypsin inhibitor motif, protease domain and C-terminal PDZ domains (reviewed in ref. 4). The role of HtrA3 is not well-characterized however the above-mentioned facts suggest similar functions for both proteins. It has been suggested that HtrA3 may be involved in human and primate placentation $(12,13)$. So far, two variants of human HtrA3
mRNA (long and short), produced through alternative splicing, have been identified (14). Both RNA isoforms encode serine proteases (50 and $40 \mathrm{kDa}$ ) which are identical in their $\mathrm{N}$ terminal parts, however the short form lacks the PDZ domain in the C-terminal region. Since it is believed that the PDZ domains are engaged in substrate binding, it is possible that the short and long forms of HtrA3 may recognize different substrates and thus have different functions (14).

It has been shown that HtrA 1 and $\mathrm{Htr} A 3$ regulate biological processes by modulating the TGF- $\beta$ (transforming growth factor $ß$ ) system. Both HtrA proteins inhibited TGF- 3 signaling with protease activity being required for the signal inhibition $(15,16)$. TGF- $\beta$ proteins are potent growth inhibitors with tumor-suppressing activity. During the first stages of tumorigenesis TGF- $\beta$ proteins may act as tumor suppressors, 
Table II. Primers used in the RT-PCR experiments.

\begin{tabular}{|c|c|c|}
\hline Gene & Oligonucleotide sequence $\left(5^{\prime}-3^{\prime}\right)$ & PCR product size $(\mathrm{bp})$ \\
\hline \multirow[t]{2}{*}{ HtrAl } & CGGAAGATGGACTGATCGTGAC & \\
\hline & GGTGATGGCTTTTCCTTTGGCC & 506 \\
\hline \multirow[t]{2}{*}{ HtrA2 } & CCCTATCTCGAACGGCTCAGG & \\
\hline & CCATGCTGAACATCGGGAAAGC & 639 \\
\hline \multirow[t]{2}{*}{$H t r A 3$} & CGTGGTGTCCAGCAACAGTGC & \\
\hline & CCGTGTGATGCGGTCTGAGGG & 445 \\
\hline \multirow[t]{2}{*}{$T G F-\beta 1$} & GCTAATGGTGGAAACCCACAACG & \\
\hline & GAAGCAATAGTTGGTGTCCAGGG & 529 \\
\hline \multirow[t]{2}{*}{$\beta$-actin } & GGAGTCCTGTGGCATCCACGAAACTAC & \\
\hline & CACATCTGCTGGAAGGTGGACAGCG & 261 \\
\hline
\end{tabular}

however, at the advanced stages, they may act as stimulators of tumor progression, invasion and metastasis (17).

Human HtrA2 (Omi) was originally described as a protein involved in the cellular stress response (18) and ischemia/ reperfusion injury (19). HtrA2 is a unique HtrA family member localized in the intermembrane mitochondrial space. Upon apoptotic stimuli, HtrA2 is released into the cytosol where it induces apoptosis, mainly by suppressing the activity of the inhibitor of apoptosis proteins (IAPs) (20-23). It has also been reported that the mutation of mouse HtrA 2 causes a neurodegenerative disease due to progressive mitochondrial damage; it has been suggested that the primary function of HtrA2 is to deal with misfolded mitochondrial proteins (24). So far, no evidence exists showing HtrA2 involvement in oncogenesis, however, such involvement seems possible since HtrA2 is involved in apoptosis, a process which is impaired in oncogenesis. The function of HtrA4 is unknown.

In the presented study, the expression of human HtrAl, HtrA2, HtrA3 and TGF- $\beta 1$ genes in endometrial cancers $(\mathrm{n}=88)$ and normal endometrium $(\mathrm{n}=36)$ was evaluated by semi-quantitative RT-PCR and Western blotting methods. The HtrA4 expression was not monitored because the anti-HtrA4 specific antibodies are not available yet. The correlations between the examined gene expression, tissue type and clinicopathological characteristics of tumors were analyzed.

\section{Materials and methods}

Patients and tissue samples. Tissue samples were obtained from 88 endometrial cancers and 36 normal endometria after surgery at the Medical University of Gdansk. The normal endometrial tissues were from peri- and postmenopausal patients operated due to benign disorders of the genital tract (uterine myomas or ovarian cysts). The samples were frozen in liquid nitrogen and stored at $-80^{\circ} \mathrm{C}$. The collecting of tissues was supervised by a pathologist. One part of every tissue sample was frozen in liquid nitrogen and used for the mRNA and protein assays; the second part was fixed in formalin and subsequently was histopathologically diagnosed. The surgical stage was established according to the International Federation of Gynecology and Obstetrics (FIGO) staging system. Histological classification and grading was defined according to the WHO system. The tumor characteristics are presented in Table I. The patients were considered as premenopausal if their menstrual cycles were regular and perimenopausal or postmenopusal if the menstruations had ceased 1-2 years or at least 3 years before surgery, respectively.

RNA isolation. Total RNAs were extracted from endometrial tissues (20-50 mg) by a modified Chomczynski procedure using a 'Total RNA' purification kit (A\&A Biotechnology, Poland) as described previously (25). The total RNA was quantified by a spectrophotometrical measurement at $260 \mathrm{~nm}$. All RNA samples were DNase I-treated as described in (25).

Semi-quantitative $R T$-PCR. DNase I-treated RNA samples were reverse-transcribed to cDNA as described previously (25). PCR amplification conditions were determined to obtain a similar amplification efficiency for both fragments and to receive an exponential phase of the amplification. The oligonucleotide primers which amplified the fragments of the tested genes and of the housekeeping gene $B$-actin are presented in Table II. The PCR mixtures for the HtrA gene amplification contained $2 \mathrm{mM} \mathrm{MgCl} 2,0.2 \mathrm{mM}$ dNTP, $0.1 \mu \mathrm{M}$ of each $\mathrm{Htr}$ A primer, primers for $\beta$-actin gene $(0.07 \mu \mathrm{M}$ for co-amplification with HtrAl gene, $0.05 \mu \mathrm{M}$ for HtrA2 and $0.05 \mu \mathrm{M}$ for HtrA3 gene); $1 \mu \mathrm{l}$ of cDNA template and $1 \mathrm{U}$ of Taq DNA polymerase (Fermentas, Lithuania). The PCR mixtures for $T G F-\beta 1$ amplification contained $1.5 \mathrm{mM} \mathrm{MgCl}$, $0.2 \mathrm{mM}$ dNTP, $0.1 \mu \mathrm{M}$ of each $T G F-\beta 1$ primer, $0.04 \mu \mathrm{M}$ of each $\beta$-actin primer and $1 \mathrm{U}$ of DNA Taq polymerase (Fermentas). The conditions for amplification of all genes were: initial denaturation $94^{\circ} \mathrm{C}$ for $2 \mathrm{~min}$, denaturation at $94^{\circ} \mathrm{C}$ for $1 \mathrm{~min}$, primer annealing at $62^{\circ} \mathrm{C}$ for $1 \mathrm{~min}$, extension at $72^{\circ} \mathrm{C}$ for $1 \mathrm{~min}$ and final extension at $72^{\circ} \mathrm{C}$ for $5 \mathrm{~min}$. The numbers of cycles were: 26 for HtrAl, 28 for $H t r A 2$ and $H t r A 3$, and 30 for $T G F-\beta 1$. PCR reactions were performed on a PTC-200 thermal cycler (MJ Research Inc., USA) in $25 \mu 1$ volumes.

The PCR products were resolved on $1.5 \%$ agarose gels in TEA buffer and visualized by ethidium bromide staining. The resulting bands were quantified by densitometric analysis 

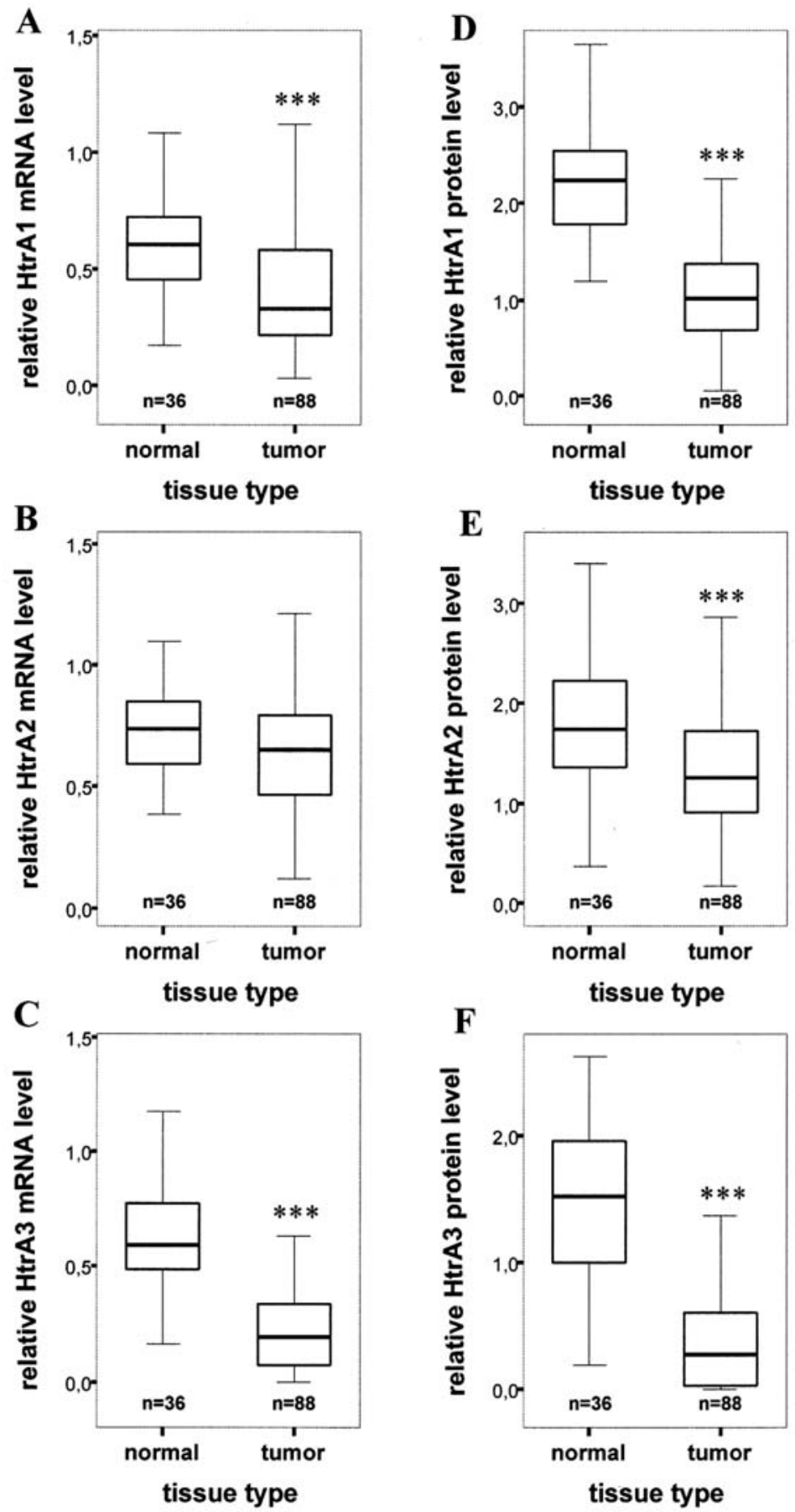

Figure 1. Expression of human HtrAl, HtrA2 and HtrA3 genes in endometrial tissues measured by semi-quantitative RT-PCR and Western blotting methods. The box plots indicate relative levels of the HtrA gene expression in endometrial cancers and normal endometrium. Relative mRNA levels are presented as a ratio of the HtrA mRNA to mRNA of the housekeeping gene B-actin. HtrA protein levels were estimated in human tissue lysates containing equal amounts of protein by the Western blotting method. Relative protein levels were calculated as a ratio of the HtrA protein band intensity in the tested sample to the HtrA intensity in the reference normal sample resolved on the same gel. The statistical significance of differences between tissue groups were determined by the Kruskal-Wallis test. ${ }^{* * *} \mathrm{p} \leq 0.001$.

and the relative mRNA levels were estimated after normalization with $B$-actin mRNA.

Western blot analysis. Protein extracts were prepared from frozen tissue samples and the total protein concentration was determined by the Bradford method as described previously (25). Tissue lysates containing equal amounts of total protein were separated by SDS-PAGE. The separated proteins were electroblotted to Immobilon P (Millipore, Poland) and then probed with primary and secondary antibodies. To detect proteins of interest an enhanced chemiluminescence system was used according to the supplier's protocol (Lumi-Light Western Blotting substrate; Roche, Poland). The tested tumor and normal tissue samples were resolved on the same gel together with a reference sample and prestained molecular weight markers (Fermentas, Lithuania). The same normal tissue sample was used as the reference in all assays for the given HtrA protein. The chosen reference sample was the 

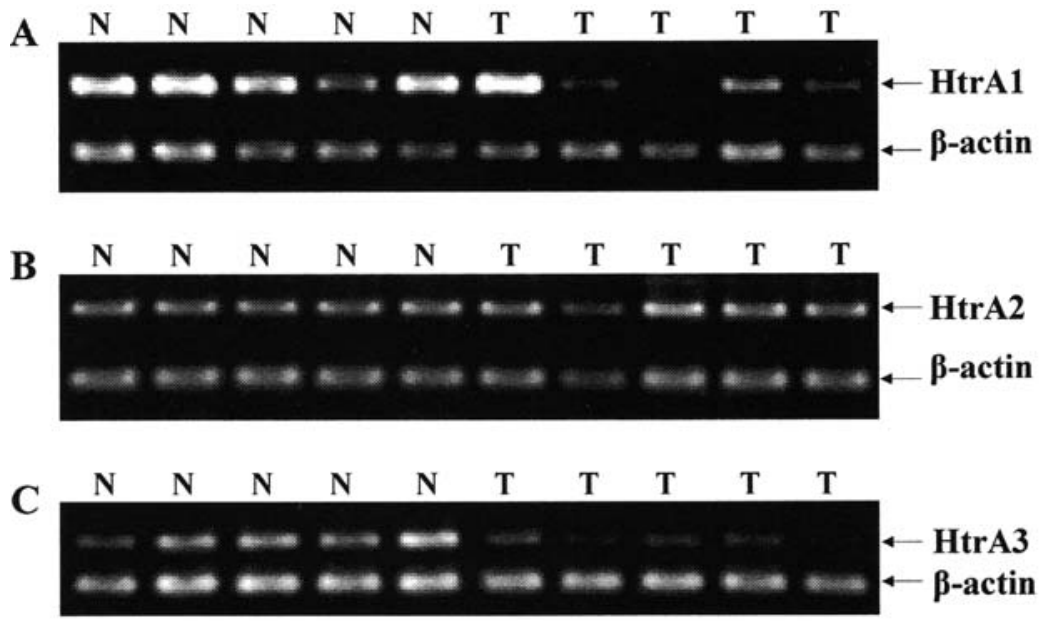

Figure 2. Levels of HtrAl (A), HtrA2 (B) and HtrA3 (C) mRNA in endometrial tumors (T) and normal endometrial tissues (N). Representative semiquantitative RT-PCR results.

one which showed the HtrA protein level close to average (the average for the normal tissues). Each assay was repeated three times and the differences between assays did not exceed $10 \%$.

The polyclonal anti-HtrA1 and anti-HtrA2 antibodies were raised in rabbits as described previously (25). The polyclonal anti-HtrA3 antibodies were purchased from Abgent, USA. The monoclonal anti-TGF- $\beta 1$ antibodies were from Abcam, UK. As secondary antibodies, anti-rabbit or antimouse HRP-conjugated immunoglobulins were used (Sigma, Poland).

Densitometric and statistical analysis. To quantify the levels of the PCR and Western blotting products, densitometric analysis was done using 1Dscan EX 3.0 program (Scanalytics, Inc). Statistical analysis was performed using SPSS 12.0 for Windows. The association between the examined gene expression, tissue types and clinicopathological characteristics of patients was evaluated by the nonparametric KruskalWallis test. The correlations were evaluated using the Spearman correlation coefficient. Results were considered significant at $\mathrm{p}<0.05$.

\section{Results}

HtrA1, HtrA2 and HtrA3 mRNA levels in endometrial cancers. The total RNAs from the cancer and normal endometrial tissues were extracted, reverse-transcribed and the HtrA cDNA was amplified in multiplex semi-quantitative RT-PCR, with a $261 \mathrm{bp}$ fragment of $\beta$-actin as a reference. Relative mRNA levels were calculated as a ratio between the yield of each amplified product and the co-amplified reference gene.

RT-PCR products corresponding to the HtrAl, HtrA2 and HtrA3 genes were detected in all the samples tested. In the case of the HtrA3 gene, the mRNA region common to both long and short isoforms of HtrA3 was amplified. This region encodes the N-terminal parts of both HtrA3 isoforms, which are identical.

A significant decrease of HtrAl and HtrA3 mRNA levels was observed in endometrial cancers compared to the normal group ( $\mathrm{p}=0.000$ in both cases). For HtrAl a 1.8-fold and for
HtrA3 a 3.2-fold decrease was observed (Table I; Fig. 1A, and $\mathrm{C})$. Moreover, we have found a significant correlation between HtrAl and HtrA3 mRNAs (r=0.541; p=0.000). HtrAl and HtrA3 mRNA levels were lower in stage III and IV tumors compared to stage I and II (Table I). Our results also showed a gradual decrease of HtrA3 mRNA with the increase of the tumor grades (measured for the endometrioid type of cancer only), however, this result was not significant statistically. We did not find any significant differences in the HtrA1/2/3 mRNA levels in different histological types of cancer (Table I).

For HtrA2, we found a slight decrease of mRNA level in the endometrial cancers compared to normal endometrium, however these results were not statistically significant (Table I; Fig. 1B). Our results also showed a significant correlation between HtrA2 and HtrA1 mRNAs ( $\mathrm{r}=0.239$; $\mathrm{p}=0.008)$, and between HtrA2 and HtrA3 mRNAs ( $\mathrm{r}=0.265 ; \mathrm{p}=0.003)$. The representative RT-PCR results for HtrAl, HtrA2 and HtrA3 are shown in Fig. 2.

Analysis carried out with endometrial cancers showed no statistically significant correlation between the tested HtrA mRNA levels and the clinical stage, histological type and grade of the tumor or menopausal status of the patients (Table I).

HtrA1, HtrA2 and HtrA3 protein levels in endometrial cancers. Endometrial tissues lysates containing equal amounts of total protein were separated by SDS-PAGE and then probed with appropriate primary and secondary antibodies. The relative levels of the tested proteins are presented as a ratio of the tested protein band intensity and the intensity of the corresponding protein in the reference sample resolved on the same gel as described in Materials and methods.

Immunoblotting with the anti-HtrA1 and anti-HtrA2 antibodies revealed bands of about 50 and $40 \mathrm{kDa}$ respectively, representing mature forms of the HtrA proteins (Fig. 3A, and B). Immunoblotting with anti-HtrA3 antibodies showed two bands of about 40 and $50 \mathrm{kDa}$, corresponding to the short and the long isoform of the protein (Fig. 3C). In the present study band intensity of the predominant short 


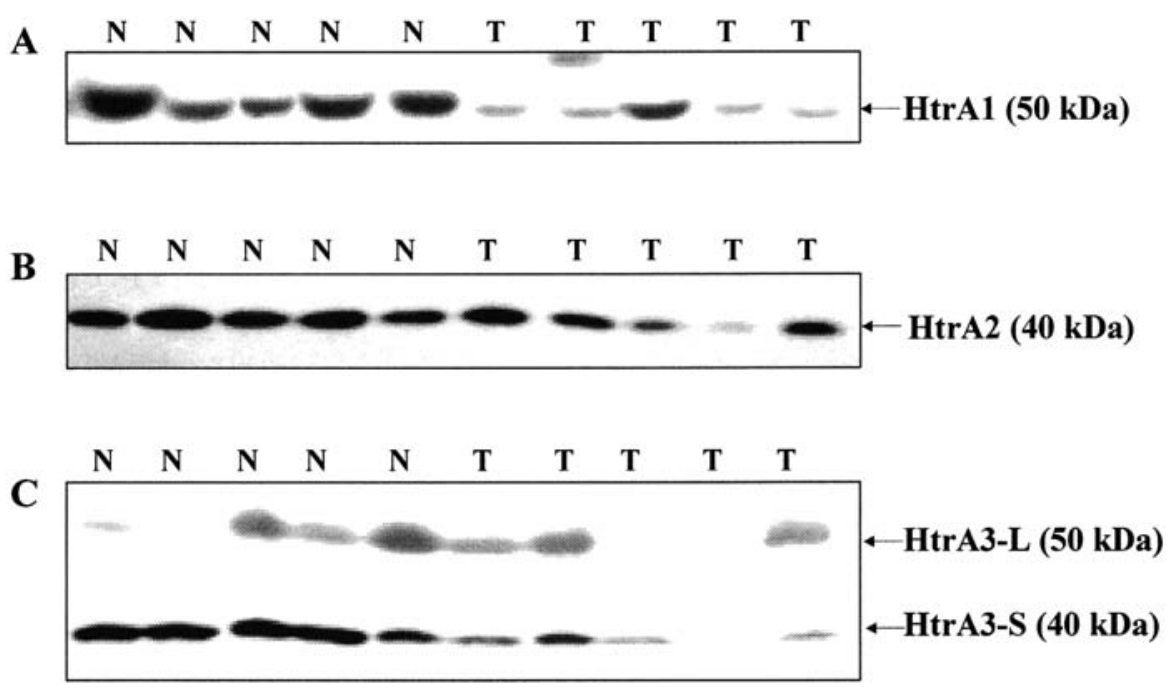

Figure 3. Levels of HtrA1 (A), HtrA2 (B) and HtrA3 (C) proteins in endometrial tumors (T) and normal endometrial tissues (N). Representative Western blotting results.
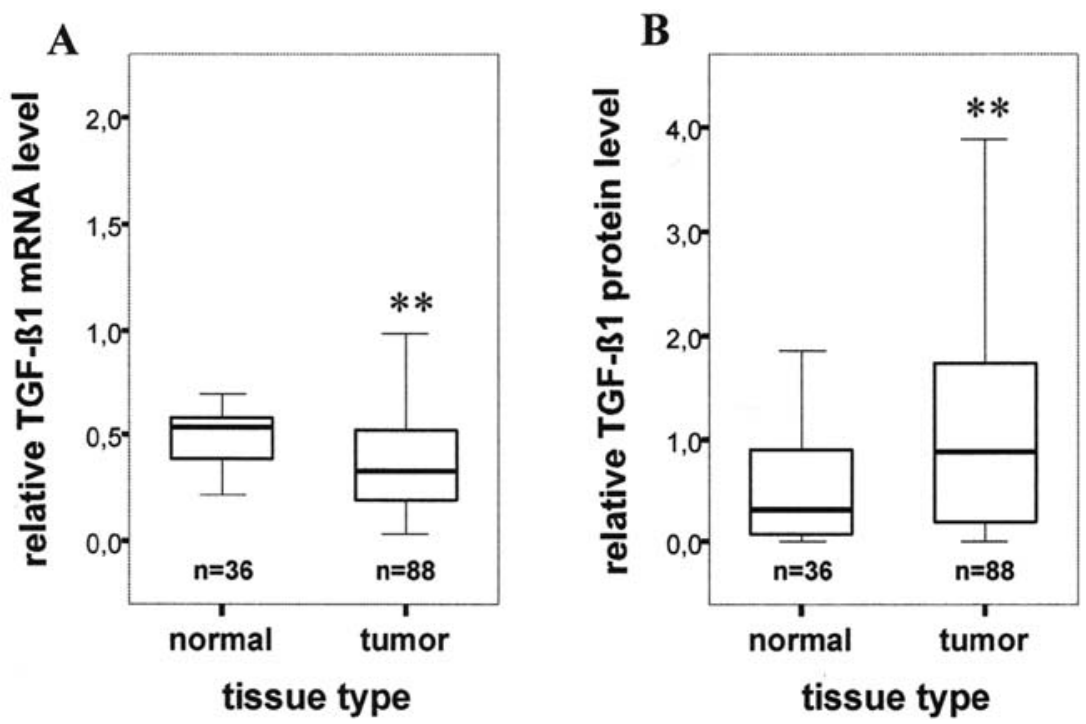

Figure 4. Expression of the TGF- $\beta 1$ gene in endometrial tissues measured by semi-quantitative RT-PCR and Western blotting methods. The box plots indicate relative levels of $T G F-\beta 1$ expression in endometrial cancers and normal endometrium. Relative mRNA levels are presented as a ratio of the TGF- $\beta 1 \mathrm{mRNA}$ to mRNA of the housekeeping gene $\beta$-actin (A). TGF- $\beta 1$ protein levels were estimated in human tissue lysates containing equal amounts of protein by the Western blotting method. Relative protein levels were calculated as a ratio of the TGF- $\beta 1$ protein band intensity in the tested sample to the TGF- $\beta 1$ intensity in the reference normal sample resolved on the same gel (B). ${ }^{* *} \mathrm{p} \leq 0.01$.

isoform was used in calculations, as the long isoform levels were usually too low to be quantified by densitometric analysis.

As presented in Table I and Fig. 1D, E and F, our results showed a statistically significant decrease of HtrA1, HtrA2 and HtrA3 (short form) proteins in endometrial cancers compared to normal tissues ( $\mathrm{p} \leq 0.001$ in all cases). The most dramatic decrease was found in the HtrA3 protein (5.6-fold). Moreover, the $\mathrm{HtrA} 3$ protein (short isoform) was not detected in $19 \%$ of the cancers, while it was detected in all normal tissues. HtrA1 and HtrA2 proteins were detected in all normal and cancer samples. Our results also showed a significant correlation between the HtrA 1 and $\mathrm{HtrA} 3$ proteins $(\mathrm{r}=0.595$; $\mathrm{p}=0.000$ ).
HtrA 1 and HtrA3 protein levels were significantly decreased in all cancer groups representing different clinical stages, histological types and grades compared to the normal group (Table I). We did not find significant differences between groups representing different grade, stage and histological type of cancer. However, we observed a gradual decrease of the short form of the HtrA3 protein level from the premenopausal to the postmenopausal group $(\mathrm{p}=0.05)$ (Table I). For the postmenopausal group, the level of HtrA3 (short form) was 2.8 -fold lower compared to the premenopausal group $(\mathrm{p}=0.017)$.

TGF- $\beta 1$ expression and correlation with HtrA proteins. $T G F-\beta 1$ expression was evaluated in all endometrial tissues 
Table III. TGF- $\beta 1$ expression in endometrial cancer and normal endometrium.

\begin{tabular}{|c|c|c|}
\hline & \multicolumn{2}{|c|}{$T G F-\beta 1$} \\
\hline & mRNA & Protein \\
\hline \multicolumn{3}{|l|}{ Total } \\
\hline Normal endometrium & 0.54 & 0.32 \\
\hline Endometrial cancer & $\begin{array}{l}0.34 \\
\mathrm{p}=0.001\end{array}$ & $\begin{array}{l}0.88 \\
\mathrm{p}=0.003\end{array}$ \\
\hline \multicolumn{3}{|l|}{ FIGO stage } \\
\hline I & 0.32 & 0.86 \\
\hline II & 0.30 & 1.02 \\
\hline III + IV & $\begin{array}{l}0.46 \\
p=0.769\end{array}$ & $\begin{array}{l}0.26 \\
p=0.884\end{array}$ \\
\hline \multicolumn{3}{|l|}{ Histological type } \\
\hline Endometrioid & 0.31 & 0.96 \\
\hline Adenosquamous & 0.23 & 0.67 \\
\hline Clear cell & 0.43 & 0.76 \\
\hline Serous & 0.46 & 3.20 \\
\hline Others & $\begin{array}{l}0.52 \\
\mathrm{p}=0.252\end{array}$ & $\begin{array}{l}0.46 \\
p=0.497\end{array}$ \\
\hline \multicolumn{3}{|l|}{ Histological grade ${ }^{a}$} \\
\hline G1 & 0.31 & 0.78 \\
\hline G2 & 0.28 & 1.09 \\
\hline G3 & $\begin{array}{l}0.37 \\
p=0.714\end{array}$ & $\begin{array}{l}1.60 \\
p=0.361\end{array}$ \\
\hline \multicolumn{3}{|l|}{ Menopausal status } \\
\hline Premenopausal & 0.44 & 0.30 \\
\hline Perimenopausal & 0.48 & 1.13 \\
\hline Postmenopausal & $\begin{array}{l}0.30 \\
p=0.451\end{array}$ & $\begin{array}{l}0.83 \\
p=0.097\end{array}$ \\
\hline
\end{tabular}

Median mRNA and protein relative values in different types of tissues are presented. P-values presenting a significant trend over the tested tissue group were found by the Kruskal-Wallis test. ${ }^{a}$ Histological grade was determined only for the endometrioid type of cancer.

used in this study by semi-quantitative RT-PCR and Western blotting methods. As shown in Table III and Figs. 4 and 5, we found a significant increase of the TGF- $\beta 1$ protein $(2.8-$ fold) and a decrease of $T G F-\beta 1$ mRNA (1.6-fold) levels in endometrial cancers compared to normal endometrium. Moreover, the TGF- $\$ 1$ protein level increased gradually with increasing tumor grades (not statistically significant).

Analysis of TGF- 31 and HtrA protein levels showed a statistically significant negative correlation between the level of TGF- 31 and the HtrA1, HtrA2 and HtrA3 levels ( $p=0.000$; $\mathrm{p}=0.000$ and $\mathrm{p}=0.006$, respectively).

\section{Discussion}

In the present study the expression of human $H \operatorname{tr} A 1, H \operatorname{tr} A 2$, $H \operatorname{tr} A 3$ and $T G F-\beta 1$ genes was estimated in endometrial

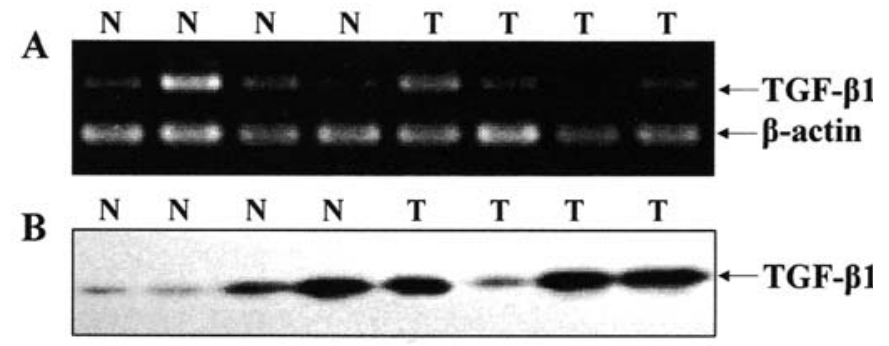

Figure 5. Expression of $T G F-\beta 1$ gene in endometrial tumors (T) and normal endometrium (N). Representative semi-quantitative RT-PCR (A) and Western blotting results $(\mathrm{B})$.

tissues, including endometrial cancers $(n=88)$ and normal endometrium $(n=36)$. The relative mRNA and protein levels, determined by semiquantitative RT-PCR and Western blotting methods, were correlated with the clinicopathological characteristics of the tumors. Moreover, correlations between the TGF- $\beta 1$ expression and expression of the HtrA1/2/3 genes were evaluated.

Our results showed a statistically significant decrease of HtrAl and HtrA3 mRNAs and of HtrAl/2/3 protein levels in endometrial cancers compared to normal endometrium. Several previous reports showed downregulation of the HtrAl and HtrA3 genes in cancers, suggesting a tumor suppressor role for these genes. The first report showed down-regulation of HtrAl mRNA and protein in SV-40 transformed human fibroblasts (5). Other studies showed downregulation of HtrAl expression in melanoma (10) and in cancer cell lines including brain, breast, liver and cervical cancers (8). Expression of HtrA3 was downregulated in lung cancer cell lines (Thompson D, et al, AACR Meeting: abs. B20, 2006). Recently, a work by Bowden et al (9) was published, in which the authors presented HtrAl and HtrA3 downregulation in endometrial cancers. Moreover, it was shown that both HtrA1 and HtrA3 protein levels decreased with increasing grades of the cancer (9). In this study, we have shown the decrease of expression of HtrA 1 and HtrA3 in a representative group of patients $(n=124)$. However, we were not able to find significant differences in the HtrA genes expression between cancers representing different grades. Though the HtrA3 mRNA level decreased gradually with the increase of tumor grade, the decrease was not statistically significant. Previous work showed that the HtrA3 protein level was significantly lower in grades G2 and G3 compared to grade G1 (9). We did not observe a similar phenomenon, however, in our studies the level of a highly dominant short isoform of HtrA3 was analyzed while in the previous work the common form of the protein was evaluated. Furthermore, previously the immunohistochemical method was used, while we applied the Western blotting technique. Thus, a different methodology could be the reason for the discrepancies, however, it should be noted that testing a large group of cancers we did not find significant differences in the HtrA3 mRNA levels for various tumor grades. We believe that our study, comprising 36 normal and 88 cancer tissues, contributes significantly towards understanding the HtrA regulation in endometrial cancer. However, further work is clearly required to fully solve the regulation patterns. 
An interesting finding is the significant correlation between the HtrA3 protein level in tumors and the menopausal status of patients. The HtrA3 protein level (short form) decreased gradually from the premenopausal to the postmenopausal group; in postmenopausal group, the HtrA3 level was 2.8-fold lower compared to premenopausal group $(\mathrm{p}=0.017)$. Since endometrial cancer is typical for postmenopausal women, it is tempting to speculate that the decrease in the short form of $\mathrm{Htr} \mathrm{A} 3$ in this group may render them more prone to oncogenesis.

Downregulation of the expression of both HtrAl and $H t r A 3$ genes in endometrial cancers, as well as the significant correlation between both mRNAs and proteins $(\mathrm{p}=0.000$ in both cases) suggest that these proteins may have similar functions. Moreover, HtrA1 and HtrA3 present similar domain organization with the $\mathrm{N}$-terminal signal peptide, an insulin growth factor binding domain (IGFBP), the trypsin-like serine protease domain, the Kazal-type $S$ protease inhibitor domain and PDZ domains (reviewed in ref. 4).

However, there are some indications that the HtrAl and HtrA3 roles may be different. Though a correlation between the expression of these genes was found, the downregulation of HtrA3 was much more dramatic. Furthermore, the short form of the HtrA3 protein was not detected in $19 \%$ of the cancers, while the HtrA1 protein was detected in all samples. Moreover, the HtrA3 but not HtrA1 protein level decreased gradually from the pre- to the postmenopausal patient group. The different expression patterns of both genes are in agreement with previous findings suggesting their different or complementary roles. Nie et al showed very different HtrA mRNA expression patterns in various human tissues, suggesting tissue-specific functions (14). Further studies are necessary to explain the possible differences in $\mathrm{HtrAl}$ and HtrA3 roles.

In Western blotting experiments with the anti-HtrA3 antibody, we detected two bands of about 50 and $40 \mathrm{kDa}$ (Fig. 3) corresponding to the long and short isoforms of HtrA3; similar results were obtained previously for endometrial (9) and ovarian tissues (25). So far, two isoforms of HtrA3 produced through alternative splicing have been identified. It was shown that both isoforms of HtrA3 transcripts were present in a range of human tissues with long (heart, skeletal muscle) or short form (placenta, kidney) being predominant in some of them. Moreover, only long (lung, small intestine) or short (brain) isoform was detected in some tissues (14). The short HtrA3 isoform was highly predominant (Fig. 3C) and thus this isoform was used in our analyses. It is tempting to speculate that since the short isoform of HtrA3 is predominant in endometrial tissues, it may play a dominant role in endometrial tumorigenesis. Both isoforms of HtrA3 are serine proteases, however, lack of the PDZ domain in the short isoform suggests that they may recognize different substrates and thus play different functions (14). Explanation of the precise functions of both isoforms requires further studies.

The mechanism of downregulation of the HtrA genes in endometrial cancer is not known. Chien et al showed that the HtrAl locus is subject to a loss of heterozygosity at the HtrAl locus (10q26) and its epigenetic inactivation by hypermetylation in ovarian tumors (8). The mechanism of $\mathrm{HtrA3}$ downregulation in cancer remains to be solved.
The level of HtrA2 protein in endometrial cancers was significantly lower compared to normal tissues $(\mathrm{p}=0.001)$. The HtrA2 mRNA levels were also lower, however, the difference was not statistically significant. Such discrepancy could result from differences in post-transcriptional and/or postranslational regulation of the HtrA2 gene in normal and cancer tissues. HtrA2 is a unique HtrA family member localized to mitochondrial intermembrane space. Upon apoptotic stimuli the protein is released to cytosol where it binds IAPs and promotes apoptosis (20-23). The possible role of HtrA2 in oncogenesis remains unexplained, however its decreased level in endometrial cancers suggests that HtrA2 may be involved in the development of malignancy. To our knowledge, the decrease of HtrA2 protein in endometrial cancer has not been reported before. Low levels of HtrA2 can lead to a reduction of the apoptosis-promoting activity and thus to increased cell proliferation which contributes to cancer development and progression. There are many investigations aimed at the discovery of new IAP inhibitors which could be useful for cancer treatment. HtrA2 is one of the potential targets for induction of apoptosis in cancer cells. It has been shown that HtrA2 is a mediator of cisplatin-induced cell death in renal cells. Cisplatin treatment of renal cells led to the upregulation and release of HtrA2 from mitochondria to cytoplasm as well as XIAP degradation, while downregulation of HtrA2 rendered cells resistant to cisplatininduced apoptosis (26).

Our results showing downregulation of the HtrAl and $H \operatorname{trA} 3$ genes support previous reports suggesting that both genes may act as tumor suppressors, however, the molecular mechanisms of the HtrA1 and HtrA3 function are not understood as yet. It was shown that both proteins are involved in the regulation of growth factor systems; both proteins can bind to TGF- $\beta$ family members and inhibit TGF- $\beta$ signaling. The mechanism of TGF- $\beta$ signaling inhibition by HtrAs' is not clear, however it was suggested that HtrAs may degrade the TGF- $\beta$ receptors or different extracellular proteins involved in regulation of TGF- $\beta$ signaling $(15,16)$. The transforming growth factor $\beta 1(T G F-\beta 1)$ is a potent growth inhibitor with tumor-suppressing activity. During the first stages of tumorigenesis TGF- $ß 1$ acts as a tumor suppressor, however, at the advanced stages it stimulates tumor progression, invasion and metastasis. Several reports showed overexpression of $T G F-\beta 1$ in human cancers and loss of response to TGF- $\beta 1$ as a growth inhibitor (17). Our results showed a statistically significant increase of protein level (2.8-fold) and a small (but significant) decrease of mRNA level (1.6-fold) in endometrial cancers compared to normal endometrial tissues. Moreover, the TGF- $\beta 1$ protein level increased gradually with increasing tumor grades. These results suggest that an elevated TGF- $ß 1$ protein level may contribute to the development of endometrial cancer. It remains to be solved why in spite of the decrease in mRNA there is an increase in the TGF- 31 protein. A possible explanation could be that a post-transcriptional or post-translational regulation is involved. It is an attractive hypothesis that the decrease of the HtrA protease levels in cancer tissues could be responsible for the observed increase of TGF- $\beta 1$ protein. Indeed, correlation analysis between the levels of the HtrA1/2/3 and TGF- $\beta 1$ proteins showed a significant negative correlation between TGF- 31 
and all HtrA proteins, which suggests involvement of HtrA proteins in TGF- $B 1$ protein regulation. Such correlations have not been found in ovarian cancer (25), indicating that TGF- $\beta 1$ regulation by HtrA may be tissue-specific. It is possible that extracytoplasmic HtrA1 and 3 proteases interact directly or indirectly with TGF- $\beta 1$, however involvement of intracellular HtrA2 in TGF- $\beta 1$ regulation is difficult to explain at the present stage.

In conclusion, our analysis of the HtrAl/2/3 and $T G F-\beta 1$ genes expression in a large group of cancer $(n=88)$ and normal $(n=36)$ endometrial tissues confirms the downregulation of HtrAl and HtrA3, as well as adding new data on the correlation between $\mathrm{HtrAl} / 3$ expression and tumor grades. It also shows that the HtrA3 protein level decreases from the premenopausal to the postmenopausal group, while for the first time showing a decrease of HtrA2 protein level in EC, and suggesting the involvement of HtrA proteins in TGF- $\beta$ signaling in EC development.

\section{Acknowledgments}

The authors thank Dr Andrzej Semczuk for critically reading the manuscript. This work was supported by grants from the Polish Committee of Scientific Research (No. 2P04A 03826) and from the Polish Ministry of Science and Higher Education (No. 3907/P01/2006/31).

\section{References}

1. Voskuil DW, Monninkhof EM, Elias SG, Vlems FA and van Leeuwen FE: Physical activity and endometrial cancer risk, a systematic review of current evidence. Cancer Epidemiol Biomarkers Prev 16: 639-648, 2007.

2. Lipinska B, Zylicz M and Georgopoulos C: The HtrA (DegP) protein, essential for Escherichia coli survival at elevated temperatures, is an endopeptidase. J Bacteriol 172: 1791-1797, 1990.

3. Spiess C, Beil A and Ehrmann M: A temperature-dependent switch from chaperone to protease in a widely conserved heat shock protein. Cell 97: 339-347, 1999.

4. Clausen T, Southan C and Ehrmann M: The HtrA family of proteases: implications for protein composition and cell fate. Mol Cell 10: 443-455, 2002.

5. Zumbrunn J and Trueb B: Primary structure of a putative serine protease specific for IGF-binding proteins. FEBS Lett 398: 187-192, 1996

6. Hu S-I, Carozza M, Klein M, Nantermet P, Luk D and Crowl RM: Human HtrA, an evolutionarily conserved serine protease identified as a differentially expressed gene product in ostheoarthritic cartilage. J Biol Chem 273: 34406-34412, 1998.

7. Shridhar V, Sen A, Chien J, Staub J, Avula R, Kovats S, Lee J, Lillie J and Smith DI: Identification of underexpressed genes in early- and late-stage primary ovarian tumors by suppression subtraction hybridization. Cancer Res 62: 262-270, 2002.

8. Chien J, Staub J, Hu S-I, Erickson-Johnson MR, Couch FJ, Smith DI, Crowl RM, Kaufmann SH and Shridhar V: A candidate tumor suppressor HtrA1 is downregulated in ovarian cancer. Oncogene 23: 1636-1644, 2004.

9. Bowden MA, Di Nezza-Cossens LA, Jobling T, Salamonsen LA and Nie G: Serine proteases HTRA1 and HTRA3 are downregulated with increasing grades of human endometrial cancer. Gynecol Oncol 103: 253-260, 2006.

10. Baldi A, De Luca A, Morini M, Battista T, Felsani A, Baldi F, Catricala C, Amantea A, Noonan DM, Albini A, Natali PG, Lombardi D and Paggi MG: The HtrA1 serine protease is downregulated during human melanoma progression and represses growth of metastatic melanoma cells. Oncogene 21: 6684-6688, 2002.
11. Chien J, Aletti J, Baldi A, Catalano V, Muretto P, Keeney GL, Kalli KR, Staub J, Ehrmann M, Cliby WA, Lee YK, Bible KC, Hartmann LC, Kaufmann SH and Shridhar V: Serine protease HtrA1 modulates chemotherapy-induced cytotoxicity. J Clin Invest 116: 1994-2004, 2006.

12. Bowden MA, Li Y, Liu YX, Findlay JK, Salamonsen LA and Nie G: HTRA3 expression in non-pregnant rhesus monkey ovary and endometrium, and at the maternal-fetal interface during early pregnancy. Reprod Biol Endocrinol 6: 22, 2008.

13. Nie G, Hale K, Li Y, Manuelpillai U, Wallace EM and Salamonsen LA: Distinct expression and localization of serine protease HtrA1 in human endometrium and first-trimester placenta. Dev Dyn 235: 3448-3455, 2006.

14. Nie G-Y, Hampton A, Li Y, Findlay JK and Salamonsen LA: Identification and cloning of two isoforms of human HtrA3, characterization of its genomic structure and comparison of its tissue distribution with HtrA1 and HtrA2. Biochem J 371: 39-48, 2003.

15. Oka C, Tsujimoto R, Kajikawa M, Koshiba-Takeuchi K, Ina J, Yano M, Tsuchiya A, Ueta Y, Soam A, Kanda H, Matsumoto M and Kawaichi M: HtrA1 serine protease, inhibits signaling mediated by Tgfß family proteins. Development 131: 1041-1053, 2004.

16. Tocharus J, Tsuchiya A, Kajikawa M, Ueta Y, Oka C and Kawaichi M: Developmentally regulated expression of mouse HtrA3 and its role as an inhibitor of TGF-beta signaling. Dev Growth Differ 46: 257-274, 2004.

17. Akhurst RJ and Derynck R: TGF- $\beta$ signaling in cancer - a double-edged sword. Trends Cell Biol 11: 44-51, 2001.

18. Gray CW, Ward RV, Karran E, Turconi S, Rowles A, Viglienghi D, Southan C, Barton A, Fantom KG, West A, Savopoulos J, Hassan NJ, Clinkenbeard H, Hanning C, Amegadzie B, Davis JB, Dingwall C, Livi GP and Creasy CL: Characterization of human HtrA2, a novel serine protease involved in the mammalian cellular stress response. Eur J Biochem 267: 5699-5710, 2000.

19. Faccio L, Fusco C, Chen A, Martinotti S, Bonventre JV and Zervos AS: Characterization of a novel human serine protease that has extensive homology to bacterial heat shock endoprotease $\mathrm{HtrA}$ and is regulated by kidney ischemia. J Biol Chem 275: 2581, 2000.

20. Suzuki Y, Imai Y, Nakayama H, Takahashi K, Takio K and Takahashi R: A serine protease, HtrA2, is released from the mitochondria and interacts with XIAP, inducing cell death. Mol Cell 8: 613-621, 2001.

21. Hegde R, Srinivasula SM, Zhang Z, Wassell R, Mukattash R, Cilenti L, DuBois G, Lazebnik Y, Zervos AS, FernandesAlnemri T and Alnemri ES: Identification of Omi/HtrA2 as a mitochondrial apoptotic serine protease that disrupts inhibitor of apoptosis protein-caspase interaction. J Biol Chem 277: 432-438, 2002.

22. Martins LM, Iaccarino I, Tenev T, Gschmeissner S, Totty NF, Lemoine NR, Savopoulos J, Gray CW, Creasy CL, Dingwall C and Downward J: The serine protease Omi/HtrA2 regulates apoptosis by binding XIAP through a reaper-like motif. J Biol Chem 277: 439-444, 2002.

23. Verhagen AM, Silke J, Ekert PG, Pakusch M, Kaufmann H, Connolly LM, Day CL, Tikoo A, Burke R, Wrobel C, Moritz RL, Simpson RJ and Vaux DL: HtrA2 promotes cell death through its serine protease activity and its ability to antagonize inhibitor of apoptosis proteins. J Biol Chem 277: 445-454, 2001.

24. Jones JM, Datta P, Srinivasula SM, Li W, Gupta S, Zhang Z, Davies E, Hajnoczky G, Saunders TL, Van Kauren ML, Fermandes-Alnemi T, Meisler MH and Alnemri ES: Loss of mitochondrial protease activity causes the neuromuscular disorder of mnd2 mutant mice. Nature 425: 721-727, 2003.

25. Narkiewicz, J, Klasa-Mazurkiewicz D, Zurawa-Janicka D, Skorko-Glonek J, Emerich J and Lipinska B: Changes in mRNA and protein levels of human $\mathrm{HtrA} 1, \mathrm{HtrA} 2$ and $\mathrm{HtrA} 3$ in ovarian cancer. Clin Biochem 41: 561-569, 2008.

26. Cilenti L, Kyriazis GA, Soundarapandian MM, Stratico V, Yerkes A, Park KM, Sheridan AM, Alnemri ES, Bonventre JV and Zervos AS: Omi/HtrA2 protease mediates cisplatin-induced cell death in renal cells. Am J Physiol Renal Physiol 288: F371-F379, 2005. 